\title{
NOTAS INTRODUTÓRIAS SOBRE A RÁDIO JOVENS HAITIANOS PROGRESSISTAS NO BRASIL
}

\author{
CRISTÓVÃO DOMINGOS ALMEIDA \\ UNIVERSIDADE FEDERAL DO PAMPA \\ SÃO BORJA, RIO GRANDE DO SUL, BRASIL \\ CRISTOVAOALMEIDA@GMAIL.COM
}

HTTP://DX.DOI.ORG/10.5902/2316882X27666 
NOTAS INTRODUTÓRIAS SOBRE A RÁDIO JOVENS HAITIANOS PROGRESSISTAS NO BRASIL

Resumo: Apresenta-se a Rádio, criada pelos haitianos, como espaço de trocas e socialização de conteúdos, visando ações concretas para se ter acessos aos bens, serviços e direitos. O estudo é de cunho qualitativo, apoiado em entrevistas. Constata-se o uso criativo das tecnologias e a necessidade de se ampliar o sentido de comunicação destinado a esses imigrantes, possibilitando estratégias na construção da rede migratória. Palavras-chave: Haitianos; Juventude; Migração; Rádio.

\section{NOTAS INTRODUCTORIAS SOBRE RADIO JÓVENES HAITIANOS PROGRESISTAS EN BRASIL}

Resumen: Se presenta la Radio, creada por los haitianos, como espacio de intercambios y socialización de contenidos, buscando acciones concretas para acceder a los bienes, servicios y derechos. El estudio es de cuño cualitativo, apoyado en entrevistas. Se constata el uso creativo de las tecnologías y la necesidad de ampliar el sentido de comunicación destinado a esos inmigrantes, posibilitando estrategias en la construcción de la red migratoria.

Palabras clave: Haití; Juventud; Migración; Radio.

INTRODUCTORY NOTES ON RADIO HAITIAN YOUNG PROGRESSIVES IN BRAZIL

Abstract: The Radio, created by the Haitians, is presented as a space for exchanges and socialization of contents, aiming at concrete actions to have access to goods, services and rights. The study is qualitative, supported by interviews. We can see the creative use of the technologies and the need to broaden the sense of communication destined to these immigrants, enabling strategies in the construction of the migratory network. Keywords: Haitians; Youth; Migration; Radio. 


\section{INTRODUÇÃO}

O objetivo desse artigo é descrever a Rádio Jovens Haitianos Progressistas como espaço de socialização de conteúdos aos haitianos que estão em processo de adaptação em solo brasileiro. Os ouvintes haitianos, na sua grande maioria, chegam ao Brasil sem o domínio da língua portuguesa e precisam se informar dos acontecimentos, verificar as oportunidades no país, principalmente as ofertas de emprego para recomeçarem a vida.

A Rádio trata-se de um protagonismo dos jovens haitianos que se uniram para planejar, organizar e colocar em funcionamento a emissora radiofônica, com a possibilidade de baixar o aplicativo na plataforma android. Para compreender o protagonismo dos nove jovens haitianos que se uniram para criar a emissora, foi preciso aproximar-se da abordagem conceitual, articulando com as dimensões da teoria e da linguagem radiofônica, os quais nos ajudam a entender a rádio como espaço sociocultural e simbólico.

Considera-se também o debate a respeito da dimensão informacional e práticas de solidariedade e ajuda mútuas através da rádio, enquanto espaço de trocas, compartilhamentos e ações concretas para se ter acesso aos direitos, isto é, a comunicação radiofônica pode agilizar o processo de tomada de consciência dos ouvintes, conhecendo a si mesmo no fluxo migratório e o ambiente onde está inserido.

Metodologicamente foram realizadas entrevistas com a equipe diretiva da emissora e observação da programação radiofônica, buscando compreender o protagonismo, as lutas, os desafios na instalação da emissora e os resultados preliminares. Dentre as maiores conquistas estão o trabalho coletivo dos haitianos e a construção do estúdio da emissora, localizado no Jardim Utinga, município de Santo André, estado de São Paulo.

Nessa dimensão do protagonismo, evidencia-se que o uso criativo das tecnologias para socializar informações e conhecimentos garantem acesso a bens, serviços e direitos, bem como as oportunidades de interações, uma vez que o ouvinte pode escutar as informações e falar das suas demandas, isto é, ouvir e ser ouvido são dimensões que fortalecem as práticas concretas e a rede migratória solidária.

Rev.Cad.Comun. Santa Maria, v.21, n.3, art 8, p. 147 de 165, set/dez.2017 


\section{TEORIA E A LINGUAGEM RADIOFÔNICA}

Antes de se fazer presente em 91,4\% dos lares brasileiros ${ }^{1}$, não podemos esquecer que o rádio nasceu em berço de ouro e se restringiu ao uso das chamadas 'sociedades' compostas por intelectuais, empresários e políticos. Foram esses grupos os primeiros a se apropriar desta tecnologia com o objetivo de atender as suas demandas econômicas, educativas ou culturais.

Interligado a isso, decorreu a popularização tecnológica; a disposição de ser compreendido por um público cada vez mais plural e a intensificação do mercado publicitário fez, e continuam fazendo, do rádio um eficaz meio a serviço da transmissão ao vivo dos fatos atuais. O rádio trouxe a possibilidade de dirigir-se a uma multidão, como o fez, em um dos momentos marcantes na história brasileira, "a primeira demonstração pública” (FERRARETTO, 2001, p. 93) durante a exposição internacional do Rio de Janeiro, que comemorava o centenário da independência, no dia 7 de setembro de 1922, com a transmissão do discurso do presidente da República Epitácio da Silva Pessoa. Por outro lado, o Rádio também foi se popularizando e tornou-se um instrumento para se escutar nos lares, com a família ou a sós. Ou seja, aos poucos, o rádio passou a ser o companheiro de todas as horas; a comunicação com os mais vulneráveis, trabalhadores rurais, com pouca formação.

Porém, de tão próximo e companheiro, muitas vezes diminuímos as causas e as consequências do ouvir e do fazer rádio. Quando tratamos da comunicação em cidades do interior, não podemos desconsiderar o potencial do rádio nessas localidades, pois estamos tratando de uma região onde a informação oficial sempre esteve dependente de algumas emissoras de rádio. Nunca foi possível saber imediatamente o que acontece em outra cidade ou mesmo no outro canto do nosso próprio bairro apenas saindo à rua, folheando jornais, revistas ou abrindo a janela da nossa casa. Podemos ter uma breve noção da complexa realidade através de boatos, atualmente muito mais acelerados por conta dos chamados fake news e dos conteúdos transmitidos pelas plataformas digitais. Mas estamos envolvidos apenas por informações, as quais, para se constituírem em co-

1 Dados divulgados em 30/03/2012 pelo Instituto de Pesquisa Econômica Aplicada (Ipea) e pela Federação Brasileira das Associações Científicas de Comunicação (Socicom).

Rev.Cad.Comun. Santa Maria, v.21, n.3, art 8, p. 148 de 165, set/dez.2017 
municação e conhecimento, necessitam de legitimação e de credibilidade.

Nesse sentido, o rádio deve ser analisado não apenas como um simples instrumento de comunicação, mas como um campo social (BOURDIEU, 2001), com regras historicamente definidas, as quais legitimam informações, constroem a credibilidade, como a realidade da realidade (FRANÇA, 2001). A diferença é abismal entre receber uma informação do seu vizinho, ou de um site, do que ouvi-la ao vivo na rádio, pela voz do locutor que admiramos. Castells (2009) alerta-nos que mesmo com a diversidade de fontes informacionais possibilitadas pela rede virtual, a credibilidade da notícia ainda está dependente dos veículos tradicionais de comunicação. Para ele, a ampliação de veículos de autocomunicação de massa (CASTELLS, 2015, p. 102) possibilita emissores e receptores de produzir e transmitir informações globais, "como é caso de um vídeo divulgado no youtube, um blog com links para várias fontes na internet, ou uma mensagem para lista de e-mail”. Nessa dimensão, os veículos de comunicação atuam como catalisadores das informações com grande visibilidade.

A legitimidade das informações e das notícias da comunicação virtual ainda busca afirmação e complementaridade nos grandes grupos midiáticos ou nos veículos de comunicação de referência. Mesmo em uma grande cidade como São Paulo, as mensagens veiculadas na mídia sobre os imigrantes contam com títulos assistencialistas, fome e desemprego, violência e até uma pergunta capciosa publicada no dia 21 de janeiro de 2016, pela Revista Isto é: “o que fazer com os haitianos?”

Os canais de comunicação reforçam uma imagem negativa dos imigrantes, daí a importância dos próprios imigrantes produzirem conteúdos com afirmação das suas lutas e vivências. Nesse contexto, cabe ao rádio ser o veículo de comunicação mais eficiente e com maior alcance, podendo ser sintonizado por brasileiros, familiares que vivem no Haiti, na França, nos EUA, no Canadá, com transmissão ao vivo, informações imediatas, sem a necessidade de edição textual ou de diagramação (WOLTON, 2007).

Através do rádio, os acontecimentos, bem como as relações sociais, são deslocados de seus contextos locais e reestruturados "[...] através de extensões indefinidas de tempo-espaço" (GIDDENS, 1991, p. 29). Ou seja, um acontecimento pode ser transmitido/recepcionado em tempo real ou reeditado e retransmitido posteriormente. A presença massiva do rádio também se deve a sua praticidade tecnológica. Trata-se de um veículo de comunicação de fácil acomodação como, sob o armário, ao lado da cama,

Rev.Cad.Comun. Santa Maria, v.21, n.3, art 8, p. 149 de 165, set/dez.2017 
dentro do carro, pendurado em uma árvore, no computador, no Ipad ou no celular, na palma da mão. Por esses e tantos outros motivos, o rádio é um meio de comunicação que se ajusta ao ouvinte e que se deixa reger pelo cotidiano de seus receptores (MATA, 2006).

$O$ rádio deixa de ser apenas um instrumento e passa a se constituir como espaço de inter-relações humanas, de contato, de afetividade. Efetiva-se como um espaço midiático dotado de potencialidades que, através da intervenção humana, ganha rumos, e orienta novos caminhos para aqueles que dele se apropriam.

Além disso, o rádio é um produtor de projetos de vida para espectadores. Em outras palavras, a tecnologia radiofônica atua não apenas como mediadora, mas como um produtor de sentidos entre os processos de produção e de recepção. Mas para isso, salienta Balsebre (1984), o estabelecimento, ou não, da comunicação depende da proximidade sociocultural entre emissor e receptor, o que nos leva a definir que a constituição da linguagem radiofônica é construída na medida em que se estabelecem outras tentativas de comunicação, que no início do rádio era considerada apenas verbal e não sonora.

A pronúncia da palavra e, posteriormente, de outros sons, puseram em curso a edificação da complexa trama da linguagem radiofônica. $O$ desenvolvimento tecnológico da produção sonora radiofônica - com a profissionalização dos roteiristas, sonoplastas, editores, diretores e locutores - possibilitou a abertura de um novo contexto perceptivo e imaginativo: com o rádio inaugura-se um modo distinto de ouvir o som.

Para Bachelard (1985), todo o planeta está ocupado em falar. Por sua vez, o rádio entra em cena e se constitui como a primeira e mais perfeita realização dessa necessidade humana. No entanto, Brecht (1981), no texto sobre teoria do rádio, alerta que uma pessoa que tem algo a dizer e não encontra ouvintes está em má situação. Também está em má situação ainda os ouvintes que não encontram quem tenha algo para lhes dizer. Brecht (1981) profetizou as potencialidades do rádio para além da capacidade de emitir mensagens, como também de receber, se conseguisse não apenas se fazer escutar pelo ouvinte, mas também pôr-se em comunicação com ele. Este aspecto é fundamental para compreendermos a diversidade de sentidos produzidos pela linguagem radiofônica, sobretudo os sentidos advindos dos processos de produção de conteúdos e não apenas da escuta ou da recepção.

Rev.Cad.Comun. Santa Maria, v.21, n.3, art 8, p. 150 de 165, set/dez.2017 


\subsection{O RÁDIO COMO ESPAÇO DEMOCRÁTICO}

O campo radiofônico necessita de uma produção orientada por um aprendizado a partir da sociabilidade. Esse espaço midiático é dotado de potencialidades e, mediante a intervenção humana, ganha rumos, como também orienta novos caminhos para os que dele se apropriam. Cogo (2012, p. 25) afirma que o espaço radiofônico possui suas lógicas, "[...] ao mesmo tempo em que também esses atores e movimentos se apropriam e reelaboram tais lógicas, transformando a esfera das mídias em um espaço simbólico de conflitos, disputas e negociações."

O rádio se afirma como estrutura/espaço de produção simbólica com um extraordinário poder de construir sentidos como a própria realidade. No entanto, alguns discursos e até mesmo pesquisas acadêmicas consideram o rádio como instrumento técnico, delegando-lhe uma posição secundária nos processos comunicacionais contemporâneos, onde o impressionismo tecnológico ocupa grande parte das nossas emoções e preocupações.

Por esse caminho, o processo de comunicação como um todo - entendido como aquele que ocorre na relação entre emissor e receptor para transmissão de uma mensagem - é alterado pela evolução das mídias digitais on-line, as quais possibilitam que o receptor também produza e transmita o seu próprio conteúdo.

No cenário multimidiático, as práticas radiofônicas web, livres ou alternativas também devem ser apropriadas ou desenvolvidas, tendo em vista os novos avanços e facilidades da produção tecnológica e da transmissão virtual. Segundo Guattari (1987), a intervenção de uma inteligência alternativa, de práticas sociais inovadoras, como é o caso das rádios web, comunitárias e livres, é indispensável para a vida das pessoas que vivem em condições de exclusão, de vulnerabilidade e invisíveis na sociedade. Estes espaços de comunicação, assegura Guattari (1987), são locais consagrados dos que não podem acessar os espaços oficiais e mercadológicos da comunicação. Tratam-se, ainda, de um instrumento de experimentação de novas modalidades de resistência, de preservação da memória, acionar as lutas em prol do acesso aos direitos, incluindo, no caso dos haitianos, no direito de informar e de ser informado. Essas situações contribuem para aperfeiçoar a democracia, ou seja, criar e garantir direitos aos sujeitos. Para Guattari (1987), as práticas radiofônicas podem ser consideradas

Rev.Cad.Comun. Santa Maria, v.21, n.3, art 8, p. 151 de 165, set/dez.2017 
como parte integrante das transformações midiáticas, ainda mais com a presença e avanço da tecnologia.

Isso está ocorrendo com a ampliação exponencial das rádios comunitárias e, mais ainda, com o avanço da rádio web. Através da internet, a rádio web pode incluir além da dimensão verbal, outros códigos, tais como a escrita e o visual. Com isso, possibilita que os ouvintes façam as interações a partir de compartilhamentos, manifestação em tempo real, ou seja, as informações são ampliadas pelos contatos que se formam em rede. A abordagem sobre rede se baseia na definição de Castells (2015, p. 65)

As redes não têm limites estabelecidos; elas são ilimitadas e têm várias bordas, e sua expansão ou contração depende da compatibilidade ou competição entre os interesses e valores programados em cada rede e os interesses e valores programados nas redes com os quais elas entram em contato em seu movimento de expansão.

É o que Castells (2015) denomina de sociedade em rede, isso significa que as redes globais estão em sintonia com as redes nacionais e locais em um espaço de propagabilidade (JENKINS, GREEN, FORD, 2015) e interações sociais. Para Castells (2015, p.66), as redes são conjuntos de nós interconectados, de modo que "todos os nós de uma rede são necessários para o seu desempenho".

As emissoras de rádio têm funcionado nessa lógica, pois são estruturas comunicativas com a possibilidade de atuarem em cooperação ou competição. O fato é que, as emissoras radiofônicas atingem diretamente as experiências de vida cotidiana das pessoas a partir de três elementos fundamentais: flexibilidade, adaptabilidade e autoconfiguração (CASTELLS, 2015).

O que se define aqui é estabelecer um novo olhar na comunicação mediada (THOMPSON, 1998), atraindo atenção de jovens e de todas as classes sociais, por isso, as emissoras radiofônicas devem ter a capacidade de serem aceitas, propagar novas vozes, fazer ouvir e gerar engajamento. Com o firme propósito de agir criticamente, produzir conteúdos capazes de despertar nos produtores e ouvintes o reconhecimento enquanto cidadãos comprometidos com as urgências de seus contextos sociais. 
Mesmo que nos refiramos ao fazer radiofônico a partir da atual conjuntura tecnológica, a utilização do rádio enquanto espaço de protagonismo juvenil não é um fenômeno contemporâneo. Rouquete-Pinto, idealizador da Rádio Sociedade Rio de Janeiro, preconizou a função educativa do rádio e, com isso, diversos jovens aprenderam a ler e a escrever, falando através das ondas do rádio especialmente nos anos 60 e 70 com a proposta dos Círculos de Cultura, iniciativa do educador Paulo Freire.

Na década de 70, o Movimento de Educação de Base (MEB) ${ }^{2}$, realizou várias práticas educativas a partir do espaço radiofônico. $O$ trabalho de alfabetização do MEB, através do rádio, é considerado um marco histórico na possibilidade de dar voz aos vulneráveis e excluídos. $O$ rádio funcionou como um espaço de mediação social entre educandos e educadores e, de certo modo, exigiu uma compreensão diferenciada ou uma dedicação exclusiva dos sujeitos envolvidos no ato de ouvir e falar. Não apenas enquanto espaço de transmissão, mas de produção de sentidos, o rádio foi se constituindo como lugar para o debate, a construção de ideias e reivindicações dos sujeitos envolvidos e essa experimentação, muito se deve aos jovens e adultos que se predispuseram a aprender novos conhecimentos a partir e através do rádio.

Deste período até os dias atuais, o uso do rádio no ambiente escolar e universitário não tem sido apenas objeto de apropriação, mas sobretudo de aprendizagens e protagonismos, visto que em diversas escolas, os jovens criam e montam as rádios que funcionam nos quinze minutos, durante o recreio, por exemplo. A apropriação do espaço radiofônico é o primeiro passo para garantir a socialização da informação. Entretanto, é preciso ir além da dimensão instrumental do meio, pois a tecnologia por si só não garante a comunicação e muito menos um processo de engajamento e protagonismo (WOLTON, 2007). Prova disso são os instrumentos tecnológicos que entram em desuso sem que a população tenha acesso, devem ser substituídos para que o conteúdo da comunicação tenha o potencial de ser difundido para o conjunto da sociedade.

Os jovens haitianos, ao planejar, montar e transmitir a emissora radiofônica, utilizaram o protagonismo, a dedicação e a criatividade, com-

2 O Movimento de Educação de Base - MEB - organismo vinculado à Conferência Nacional dos Bispos do Brasil (CNBB) comemorou, no dia 21 de março, 56 anos de criação. http://www.meb.org.br. Acesso em: 28/03/2017.

Rev.Cad.Comun. Santa Maria, v.21, n.3, art 8, p. 153 de 165, set/dez.2017 
preendidos aqui a partir da abordagem de Masi (2000, p. 206), "não é só ter ideias, mas saber realizá-las". Nessa concretização, esbarraram nos desafios relacionados à falta de um ambiente que se pudesse estruturar o estúdio, os recursos financeiros para adquirir os equipamentos e as burocracias sobre a documentação. Nesse sentido, Masi (2000, p.208) constata que "educar um jovem para a criatividade hoje significa ajudá-lo a identificar sua vocação autêntica, ensiná-lo a escolher os parceiros adequados, a encontrar e criar contextos mais propícios a criatividade".

Nessa perspectiva, um imigrante, provisório ou duradouro (SAYAD, 1998), que utiliza o protagonismo e a criatividade enquanto processos mobilizadores para produzir e divulgar informações através do rádio, gera desenvolvimento individual e contribui ativamente para a afirmação e reconhecimento dos demais imigrantes. Isto é, são pessoas com capacidade de criar, construir e realizar a leitura de mundo (FREIRE, 2005), uma vez que a mídia tradicional reafirma narrativas depreciativas, negativas e reforçam as situações de vulnerabilidade dos imigrantes.

Por isso, Freire (2005, p. 181) adverte que "a formação técnico-científica não é antagônica à formação humanista dos homens, desde que a ciência e tecnologia, devem estar a serviço de sua libertação permanente de sua humanização", como forma de expressar a heterogeneidade, as desigualdades e as diferenças que atravessam as experiências humanas.

Nesse contexto, a criação de uma emissora radiofônica pelos imigrantes haitianos tem o potencial de se configurar como uma ação de cidadania, que Mata (2006) considera como o ato de agir concretamente no ambiente onde o sujeito está inserido. Neste caso, a participação comunicacional e ativa dos haitianos contra o processo informacional que os apresentam como 'invasores', 'quem rouba trabalho dos brasileiros', discursos dominantes desencadeados pela mídia tradicional. Desse modo, a força do ato criativo, participativo e cidadã faz com que os imigrantes sintam-se capazes de reagir a este processo cultural dominante, socializando assuntos que edifiquem a vida e o viver das pessoas que optam pelo deslocamento como forma de melhorar as condições de vida e das pessoas que deixaram o país de origem.

O espaço radiofônico possibilita a integração direta entre locutores e ouvintes, aproximando os contextos e as realidades de vida. Essa aproximação facilita a comunicação, as trocas e envolve o exercício de diálogo, debate e interações em torno dos mais diversos temas e conteúdos abor-

Rev.Cad.Comun. Santa Maria, v.21, n.3, art 8, p. 154 de 165, set/dez.2017 
dados na programação radiofônica.

\subsection{PROTAGONISMO DOS JOVENS HAITIANOS: A CRIAÇÃO DA EMISSORA}

O protagonismo e a criatividade empreendedora dos haitianos iniciaram de modo simples, utilizando uma lista de contatos no aplicativo WhatsApp. O idealizador da lista conta que sentiu a necessidade de ajudar as pessoas socializando informações sobre como obter a documentação para fazer o visto, inclusive se prontificando a realizar a tradução dos documentos, quando necessário. Além disso, gravava áudio de até um minuto com informações sobre oportunidades de emprego. Esses assuntos uniam-se com a questão de onde ser acolhido, quais compatriotas podiam receber os haitianos em suas residências. Eram esses os assuntos que mereciam ser compartilhados, pois, em 2013, no auge do fluxo migratório haitiano, as preocupações de quem chegava em São Paulo eram: acolhida, documentação e acesso ao mundo do trabalho.

Com o passar dos meses, o haitiano percebeu a boa receptividade dos integrantes do grupo do WhatsApp e começou a postar informações em francês e créole, uma vez que os imigrantes recém-chegados não dominavam o português. Atento ao dinamismo e agilidade do aplicativo, ele começou a gravar informações de interesse dos haitianos em francês e créole. O haitiano relata que com o tempo percebeu: eu já tinha iniciado uma rádio no WhatsApp. A aceitação foi muito boa, os haitianos gostavam porque informava sobre fatos que eles jamais iriam saber pela mídia brasileira.

Da experiência do aplicativo, o haitiano montou a rádio web³ Power Love. O haitiano Neerwnder fala seis idiomas: francês, créole, espanhol, inglês, alemão e português, com isso, ele produz conteúdos para serem divulgados na rádio, com intuito de comunicar com os compatriotas dos países: Haiti, República Dominicana, Cuba, EUA, Canadá, França e Alemanha, locais onde existem maior presença de imigrantes haitianos. E, os ouvintes passaram a corresponder, solicitando músicas, enviando recados e notícias a serem socializados através da emissora radiofônica. 
O jovem produz os conteúdos nas horas vagas de trabalho, ele vende passagens aéreas. $O$ trabalho que ele desenvolve facilita o contato e as interações com os haitianos que chegam e saem do Brasil, porque "os meus compatriotas me procuram para comprar passagem, porque sou um deles, falo a mesma língua, realizo as explicações e eles se sentem seguros". Esse contato, tanto de quem chega no país quanto de quem sai, em deslocamento a outros países é fundamental para realizar a rede migratória. E, são eles os potenciais ouvintes da emissora, uma vez que no cartão de visita do haitiano consta os contatos pessoais e o link da rádio web.

Na rádio web, criada pelo jovem haitiano, é possível perceber a mediação da comunicação que ganha força tanto na produção, circulação dos conteúdos quanto nas ações que valorizam as informações de interesse dos imigrantes e essas mensagens também servem como espaço de união, solidariedade e de resistência, uma vez que os haitianos potencializam as suas narrativas, reforçam as suas lutas, ajudam a superar as dificuldades do cotidiano. Essas ações podem ser articuladas com o pensamento de Ricoeur (1998, p. 3), para o autor, a união, a solidariedade e a resistência "[...] ganham sentido no intercâmbio das memórias, das vivências e dos projetos de vida em comum".

\subsection{A RÁdIO JOVEM HAITIANO PROGRESSISTA}

O haitiano James, há cinco anos no Brasil, também montou uma rádio web, em Cuiabá, estado de Mato Grosso. Ele relata que sentiu a necessidade de criar uma emissora, em 2013, "para ajudar nossos irmãos com informação e formação no dia a dia". Ele optou por Cuiabá por conta das informações sobre as oportunidades de emprego na área da construção civil, pois, havia procura de mão de obra para atuarem na Arena Pantanal, instalação do VLT, viadutos, centro de treinamento, entre outros.

O haitiano James, há cinco anos no Brasil, também montou uma rádio web, em Cuiabá, estado de Mato Grosso. Ele relata que sentiu a necessidade de criar uma emissora, em 2013, "para ajudar nossos irmãos com informação e formação no dia a dia". Ele optou por Cuiabá por conta das informações sobre as oportunidades de emprego na área da construção civil, pois, havia procura de mão de obra para atuarem na Arena Pantanal, instalação do VLT, viadutos, centro de treinamento, entre outros.

James conta que não tinha experiência com locução e nem atuação

Rev.Cad.Comun. Santa Maria, v.21, n.3, art 8, p. 156 de 165, set/dez.2017 
em rádios. O interesse surgiu porque ele é programador de web. Ele cria websites, desenvolve sistemas e aplicativos para a plataforma android. Do trabalho de programação, ele percebeu que poderia criar uma rádio web para facilitar a comunicação entre os haitianos. No início, mesclava músicas haitianas e brasileiras, porém, posteriormente, ele começou a receber solicitações dos ouvintes pelo WhatApp, pois ele disponibilizou o número para verificar a aceitação. Diante disso, decidiu inserir, na programação, informações de interesse da comunidade haitiana, ao vivo, tais como: ofertas de trabalho, direitos trabalhistas, saúde, cultura e educação.

Com o tempo, os próprios haitianos manifestaram interesses para ampliar os horários ao vivo. Com isso, ele precisou incluir mais dois jovens haitianos para auxiliá-lo tanto na seleção musical, informações e edição de conteúdo. Essa reorganização foi importante porque James conta que "os irmãos compatriotas queriam notícias, saber o que está ocorrendo aqui. As notícias brasileiras eles pouco entendiam e eram distantes da nossa realidade, menos o futebol e as novelas, esses eles gostam".

Diante dessa necessidade de ampliar a programação, 24 horas no ar, o jovem haitiano que mora em Cuiabá conheceu Neerwnder que vive na capital paulista. Dois jovens, em cidades distantes, mas com os mesmos objetivos, tornaram visíveis as lutas e as demandas dos haitianos no Brasil. Por isso, a partir de atividades em prol da imigração haitiana, eles começaram a editar programas e socializar pautas a serem divulgadas nas emissoras.

O resultado desse trabalho em conjunto e solidário fez com que, em dezembro de 2016, nove jovens haitianos se unissem entorno da elaboração, montagem e lançamento da Rádio Jovem Haitiano Progressista. A estrutura organizacional ficou da seguinte forma: Rigand Robert, diretor geral; Neewender Joseph, diretor de Marketing; David Georges, diretor de programação; Ryan James, porta voz; Woodny Mompremier, administração; Jacky Mix e Michelin, apoio; Billy Murielle e Jose Ketty Delice, secretárias da rádio.

A emissora já está no $\mathrm{ar}^{4}$, com o objetivo de "revolucionar a cultura haitiana no Brasil e no mundo". A emissora conta com uma página no facebook para divulgar as suas ações. A página tem avaliação de 4,8 , considerado muito bom pelos internautas, além dos compartilhamentos, cur-

$4 \quad$ Acesse aqui: http://radiojhp.com

Rev.Cad.Comun. Santa Maria, v.21, n.3, art 8, p. 157 de 165, set/dez.2017 
tidas e comentários que as postagens recebem. Por exemplo, o vídeo, publicado no dia 23 de fevereiro, sobre o lançamento da emissora tem quase mil visualizações e 36 compartilhamentos. Isso demonstra que está ocorrendo engajamento dos ouvintes e trocas comunicacionais através das plataformas.

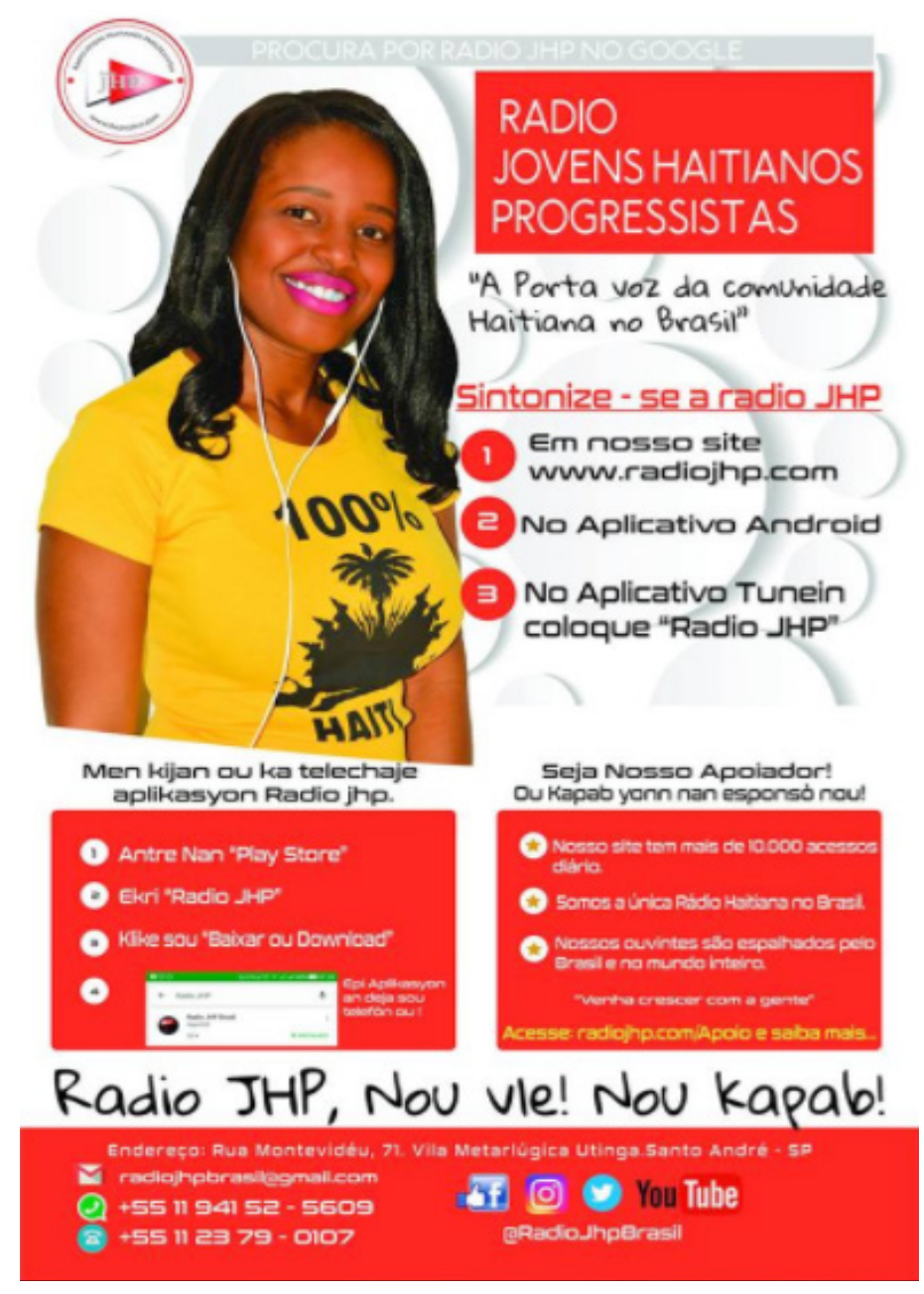

Figura 1: Divulgação da emissora

Fonte: https://www.facebook.com/RadioJhpBrasil/

O Diretor técnico e porta voz da emissora relata que a rádio web ainda é musical e noticiosa, entretanto, os jovens haitianos estão se estruturando para inserir uma nova grade com: música, informações, arte, cultura e outros temas de interesse dos ouvintes. O diretor técnico e porta voz da emissora comenta ainda que o estúdio está "pronto, recebemos um espaço físico do padre da paróquia de Utinga. Ele, a comunidade e os haitianos estão ajudando e empenhados nesse projeto". Ou seja, o maior desafio dos haitianos era ter um lugar fixo para montar o estúdio e o padre Duckson disponibilizou uma sala na paróquia aos haitianos. A paróquia conta com salas de reuniões, de catequeses, além de uma quadra coberta para ativi-

Rev.Cad.Comun. Santa Maria, v.21, n.3, art 8, p. 158 de 165, set/dez.2017 
dades culturais e esportivas. E, o padre, que também trabalha na acolhida de imigrantes, cedeu esse espaço para abrir o estúdio da rádio Jovem Haitianos Progressistas, localizado na rua Montevidéu, 71, Utinga, Santo André/SP, por compreender que a comunicação ajuda no fortalecimento das causas do migrante.

Com a formalização do projeto da rádio, James decidiu morar em São Paulo para "ter tempo para o projeto da rádio". Ele está desde fevereiro na capital, mora na região de Tatuapé com outros companheiros haitianos e diz com orgulho que já produziu o sistema aplicativo da rádio web e o ouvinte pode baixar o App na plataforma android para acompanhar a programação, "já colocamos no ar e o sistema está dando super certo".

Ele revela alguns dados da emissora, como por exemplo, o número de acessos: mais de mil ouvintes regulares e os comentários dos ouvintes com incentivos e manifestação de "desejo de que a emissora avance, cada vez mais"; "os haitianos sempre se organizam entorno de uma rádio, isso é muito bom", este último da ouvinte Meine Anny. Os comentários resultam em informações de como podem ajudar, apoiar e contribuir com a emissora.

James comemora o incentivo e a participação dos ouvintes "porque são eles que nos motivam a fazer melhor". De acordo com ele, os ouvintes que mais acessam o site da emissora e baixam o App da emissora estão localizados no Brasil, EUA, Venezuela, Haiti, Equador, Chile, Canadá, França, México, Grécia, Bélgica e Turquia.

Os dados preliminares sobre a rádio web criada pelos haitianos revelam o protagonismo e o engajamento dos imigrantes. Essas ações possibilitaram a apropriação de técnicas radiofônicas, do processo de escolha e socialização dos conteúdos e o domínio do português, mesmo que as informações sejam traduzidas para o créole e francês, a seleção das informações depende do domínio da leitura do português. Outra questão importante é a união dos jovens entorno da construção da emissora. Iniciaram individualmente, mas se uniram num trabalho coletivo para enfrentar os desafios, aqui elencadas, ausência de recursos, estrutura física, documentação, para em seguida, traçar estratégias para superá-las, ampliar o alcance e a presença da emissora no Brasil e no exterior.

O protagonismo dos jovens haitianos por meio da atividade radiofônica, articula-se com o pensamento de Kaplún (2001, p. 47), ao afirmar que "se aprende de verdad lo que se vive, lo que se recrea, lo que se reiventa 
y no lo que simplemente se lee y se escucha". Ou seja, a veiculação de informação na emissora, por si só, não tem sentido, ela precisa ter reflexo na realidade cotidiana das pessoas. As informações quando fazem sentido ao sujeito, podem auxiliar nas transformações através da conquista da moradia, do emprego, do acesso à saúde, à educação e, também podem contribuir com a construção de sujeitos críticos, livres e autônomos.

\subsection{A VOZ DOS HAITIANOS}

A Rádio Jovem Haitianos Progressistas está no ar 24 horas ao dia e quando tem programação ao vivo, aborda temas ligados à cidadania, educação, cultura, saúde, direitos sociais e trabalhistas. No rádio, que contém esse mix de mensagens, recebe um nome técnico. Alguns autores, como é o caso de Ferraretto (2001), classifica como programa de variedades. As emissoras que combinam informações e entretenimento, ou seja, para Ferraretto (2001, p. 57) "engloba da prestação de serviços à execução de músicas, passando por temas diversificados".

Para o diretor geral, Montalais Pierre, a experiência radiofônica serve como oportunidade para o desenvolvimento pessoal e coletivo e, reafirma: "é possível crescer em todos os sentidos". O protagonismo de criar e colocar em funcionamento uma emissora radiofônica, bem como a possibilidade de dizer a palavra, mesmo em um país que os acolhe, provisório ou duradouro (SAYAD, 1998), mostra a convicção dos imigrantes em se inserir num sistema de mídia que amplifica a sua voz, através de conexões, formações de redes migratórias para informação, diversão, serviços públicos, religiosidade, ação cultural e política. Por exemplo, no mês de março e abril, o tema amplamente debatido foi a nova Lei de Migração5, aprovado pelo senado no dia dezoito de abril de 2017, tratando o imigrante em condições de igualdade com direitos e deveres. Daí a observação de Kaplún (2002, p. 57), "los sectores populares no quieren seguir siendo meros oyentes; quieren hablar ellos también y ser escuchados. Pasar a ser interlocutores."

5 Revogou o Estatuto do Estrangeiro, Lei de 1980, oriunda do regime militar que, dentre outras coisas, trata das condições de entrada, impedimento, deportação, expulsão e extradição de imigrantes no Brasil, quando pegos, por exemplo, em movimentos políticos, manifestações e organizações sindicais.

Rev.Cad.Comun. Santa Maria, v.21, n.3, art 8, p. 160 de 165, set/dez.2017 
As vozes dos haitianos emergem da realidade cotidiana, com intuito de superar os desafios, enfatizando e incentivando as lutas, a criatividade, a invenção e a valorização da cultura. Na prática, os jovens haitianos desenvolvem, como diz Freire (2005, p. 82):

[...] o seu poder de captação e de compreensão do mundo que Ihes aparece, em suas relações com ele, não mais como uma realidade estática, mas como uma realidade em transformação, em processo.

Eles relatam que um dos maiores desafios está sendo a montagem da estrutura física e a aquisição dos instrumentos tecnológicos para operacionalizar o trabalho radiofônico. James fala que desde a aquisição dos equipamentos até a construção do estúdio "tivemos que pagar do nosso próprio bolso", e, acrescenta "mantemos a rádio no ar com o pouco de recursos que temos".

[...] a dificuldade está sendo enorme. Mas com ajuda de um e de outro estamos superando. Mesmo assim, o que nós não temos é medo de enfrentar os desafios e nem de falar e informar a comunidade haitiana. Somos insistentes e queremos fazer bem feito. $O$ nosso povo merece o melhor de nós. (JAMES, 11/04/2017).

Neewender compartilha desse pensamento e entusiasmo, ainda mais quando recebem retorno e participação dos ouvintes. Percebem que estão no caminho certo e que podem avançar com informações construtivas para a vida das pessoas. O haitiano explica:

[...] fico pensativo porque não sabia na prática se o quê a gente estava fazendo tinha resultados. Ler os depoimentos dos ouvintes e a gente se ouvir também foi muito importante. Agora sei que as pessoas estão ouvindo e aceitando o nosso trabalho.

A importância do trabalho unificado e coletivo é que um motiva o outro, a pesquisar, ler, escrever, organizar reuniões, participar de coberturas de eventos promovidos pelos haitianos, realizar o processo de gestão e sistematizar os fatos e acontecimentos na linguagem radiofônica. Isso significa que a Rádio Jovens Haitianos Progressistas cumpre o seu papel de ajudar os imigrantes a se informar, a criar um contexto mais propício de acesso aos direitos e, de algum modo, os imigrantes podem construir,

Rev.Cad.Comun. Santa Maria, v.21, n.3, art 8, p. 161 de 165, set/dez.2017 
coletivamente, iniciativas que os atendam na sua integralidade.

\section{CONCLUSÃo}

A criação da Rádio Jovens Haitianos Progressistas deve-se levar em conta que, antes de ser um caminho acertado, a partir do protagonismo dos jovens haitianos, trata-se também de um processo de aprender e de ensinar, coletivamente. Por isso, não se pode adotar a concepção de que os haitianos possuem pouco ou quase nada de conhecimento sobre a mídia. Uma postura pessimista poderia incorrer no erro de que o rádio é distante do cotidiano dos imigrantes e sem sentido para as pessoas que estão em deslocamento. Pelo contrário, os imigrantes, com base na experiência cotidiana, demonstram sintonia com as necessidades vividas, com a realidade da realidade (FRANÇA, 2001) e facilidade com a linguagem radiofônica.

A criação e manutenção no ar da emissora radiofônica evidencia a necessidade de se ampliar o sentido de comunicar aos imigrantes que chegam em solo brasileiro, criando processos informacionais de interesse desses sujeitos, abrindo-o para novas oportunidades, as quais ofereçam práticas concretas e socialmente comprometidas com o acesso a bens, serviços e direitos.

Portanto, a veiculação de conteúdos pela emissora radiofônica também oportuniza espaços para as trocas comunicacionais, a construção da autonomia e de postura de sujeitos críticos que, com auxílio informacional, pode considerar as expectativas atendidas, bem como os desafios e as insuficiências que precisam ser aperfeiçoadas ou melhoradas. A produção sonora não deve ficar presa a escuta dos resultados técnicos e estéticos, mas os imigrantes devem aproveitar o conteúdo para o debate político, sociológico, cultural ou mesmo de ordem existencial. 


\section{REFERÊNCIAS}

BALSEBRE, Armand. El lenguage radiofónico. Madrid: Ediciones Cátedra, 1994.

BACHELARD, Gaston. O direito de sonhar. São Paulo: DIFEL, 1985.

BOURDIEU, Pierre. Contrafogos 2: por um movimento social europeu; tradução, André Teles. Rio de Janeiro: Jorge Zahar, 2001.

BRECHT, Bertolt. Teoría de la Radio (1927-1932). In. BASSETS, Lluís (ed.). De las ondas rojas a las radios libres. Textos para la historia de la radio. Barcelona, Gustavo Gili, 1981.

CASTELLS, Manuel. Comunicación y poder. Madrid: Alianza, 2009.

. O poder da comunicação. Rio de Janeiro/São Paulo: Paz e Terra, 2015.

COGO, Denise. Latino-americanos em diáspora: usos de mídia e cidadania das migrações transnacionais. Rio de Janeiro: Tríbia, 2012.

FERIRE, Paulo. Pedagogia do Oprimido. Rio de Janeiro: Paz e Terra, 2005.

FERRARETO, Luiz Artur. O veículo, a história e a técnica. 2. Ed., Porto Alegre: Sagra Luzzatto, 2001.

FRANÇA, Vera. Paradigmas da comunicação: conhecer o que? Revista Ciberlegenda. Rio de Janeiro: UFF, edição especial, n.5, p.1-19, 2001.

GIDDENS, Anthony. As consequências da modernidade. São Paulo: Editora Unesp, 1991.

GUATTARI, Felix. Revolução molecular: pulsões políticas do desejo. São Paulo: Brasiliense, 1987. 
CADERNOS DE COMUNICAÇÃO

UNIVERSIDADE FEDERAL DE SANTA MARIA

JENKINS, Henry, GREEN, Joshua; FORD, Sam. Cultura da conexão: criando valor e significado por meio da propagável. São Paulo: Aleph, 2014.

KÁPLUN, Mario. La educación por la comunicación. 2. Ed., Quito, Equador: CIESPAL, 2001.

MASI, Domenico. Ócio criativo. 3. Ed., Rio de Janeiro: Sextante, 2000.

MATA, Maria Cristina. Comunicación y ciudadanía: problemas teórico-políticos de su articulación. Revista Fronteiras - estudos midiáticos, São Leopoldo/RS, VIII (1): 5-15, jan./abr., 2006.

SAYAD, Abdelmalek. A imigração ou os paradoxos da alteridade. São Paulo. EDUSP, 1998.

THOMPSON, John B. A mídia e a modernidade: uma teoria social de mídia. Petrópolis: Vozes, 1998.

WOLTON, Dominique. É preciso salvar a comunicação. São Paulo: Paulus, 2007. 


\section{Cristóvão Domingos Almeida}

Pós-doutor em Comunicação e Práticas de Consumo na ESPM, doutor em Comunicação e Informação pela UFRGS, mestre em Educação pela Unisinos, graduado em Relações Públicas pela Puc-Campinas e é professor na Universidade Federal do Pampa.

E-mail: cristovaoalmeida@gmail.com

RECEBIDO EM: $14 / 06 / 2017$

ACEITO EM: $14 / 08 / 2017$ 